Review

\title{
Structures and Ribosomal Interaction of Ribosome-Inactivating Proteins
}

\author{
Wei-Wei Shi, Amanda Nga-Sze Mak, Kam-Bo Wong and Pang-Chui Shaw * \\ Centre for Protein Science and Crystallography, School of Life Sciences, The Chinese University of Hong Kong, \\ Shatin, N.T., Hong Kong, China; Shiww@cuhk.edu.hk (W.-W.S.); amandamak@gmail.com (A.N.-S.M.); \\ kbwong@cuhk.edu.hk (K.-B.W.) \\ * Correspondence: pcshaw@cuhk.edu.hk; Tel.: +852-3943-1363
}

Academic Editor: Els Van Damme

Received: 10 October 2016; Accepted: 15 November 2016; Published: 21 November 2016

\begin{abstract}
Ribosome-inactivating proteins (RIPs) including ricin, Shiga toxin, and trichosanthin, are RNA $N$-glycosidases that depurinate a specific adenine residue (A-4324 in rat $28 \mathrm{~S}$ ribosomal RNA, rRNA) in the conserved $\alpha$-sarcin/ricin loop ( $\alpha$-SRL) of rRNA. RIPs are grouped into three types according to the number of subunits and the organization of the precursor sequences. RIPs are two-domain proteins, with the active site located in the cleft between the $\mathrm{N}$ - and C-terminal domains. It has been found that the basic surface residues of the RIPs promote rapid and specific targeting to the ribosome and a number of RIPs have been shown to interact with the C-terminal regions of the $\mathrm{P}$ proteins of the ribosome. At present, the structural basis for the interaction of trichosanthin and ricin-A chain toward P2 peptide is known. This review surveys the structural features of the representative RIPs and discusses how they approach and interact with the ribosome.
\end{abstract}

Keywords: ribosome-inactivating proteins; RNA N-glycosidases; ribosome; P proteins; ribosomal interaction

\section{Introduction}

RNA $\mathrm{N}$-glycosidases are very potent enzymes, and some of them are among the most potent toxins of plant origin. Ricin, one of the most toxic natural substances discovered in late 19th century by P. H. Stillmark, agglutinates red blood cells [1] and its lethal dose in humans is about $1.78 \mathrm{mg}$ for an average adult [2]. It is now known that ricin hydrolyzes the $\mathrm{N}$-glycosidic bond at adenine 4324 (A-4324) in the 28S ribosomal RNA (rRNA) of eukaryotic ribosomes [3], and in some cases A-2660 in the naked 23S rRNA of prokaryotic ribosomes [4]. This adenine is located at a GAGA hairpin within the $\alpha$-sarcin/ricin loop ( $\alpha$-SRL) [5]. The loop is highly conserved in all large ribosomal subunits and is essential for the proper assembly of the functional core of the large subunit [6]. In eukaryotes, removal of the specific adenine hinders the elongation factor 1-dependent binding of aminoacyl-transfer RNA (tRNA) and guanosine triphosphate (GTP)-dependent binding of elongation factor 2 to ribosome. In prokaryotes, damaged ribosomes do not bind elongation factor thermo unstable (EF-Tu) or elongation factor (EF) G G. As a result, protein synthesis is arrested at the elongation step [7]. rRNA $\mathrm{N}$-glycosidases are therefore also known as ribosome-inactivating proteins (RIPs). There are also other classes of proteins that inactivate ribosomes. These include phosphodiesterases such as $\alpha$-sarcin and restrictocin that inactivate ribosome through the hydrolysis of a single phosphodiester bond between G4325 and A4326 in the $\alpha$-SRL [8] and adenosine diphosphate (ADP)-ribosyltransferase such as diphtheria toxin that catalyzes the transfer of the ADP-ribose of niconiteamide adenine nucleotide (NAD) to the diphthamide moiety of EF-2 [9]. However, it is a common practice to reserve the name RIP to RNA $\mathrm{N}$-glycosidases and these two terms are used interchangeably here. 
Under physiological conditions, a single ricin A chain (RTA) molecule depurinates 1000-2000 mammalian ribosomes per minute. Naked rRNA is less susceptible to RIPs, indicating that RIPs need to bind to specific ribosomal proteins before carrying out their catalytic action [10]. Besides the RNA $N$-glycosidase activity, RIPs are also found to possess specific DNA cleavage activities on double-stranded supercoiled DNA and mitochondrial DNA [11], superoxide dismutase [12], phospholipase [13], or DNA topoisomerase inhibitory activities [14], although it is possible that some of these activities may be due to contamination in protein preparation [15]. With more than 20 RIP structures available and the recent discoveries on the RIP-ribosome interaction, we set to provide a survey on the structures of RIPs and their interaction mode with the ribosomes.

\section{Distribution and Classification of RIPs}

RIPs are widely distributed in over 100 different plant species and in different organs [16,17]. They are also found in fungi, algae, and bacteria $[18,19]$. However, some of these RIPs have very different molecular weights and $\mathrm{N}$-terminal protein sequences and may not be true RNA $\mathrm{N}$-glycosidases. RIPs might play an important role in plant physiology and defense mechanisms because some of them could be induced by development [20], stress [21], or viral infection [22,23].

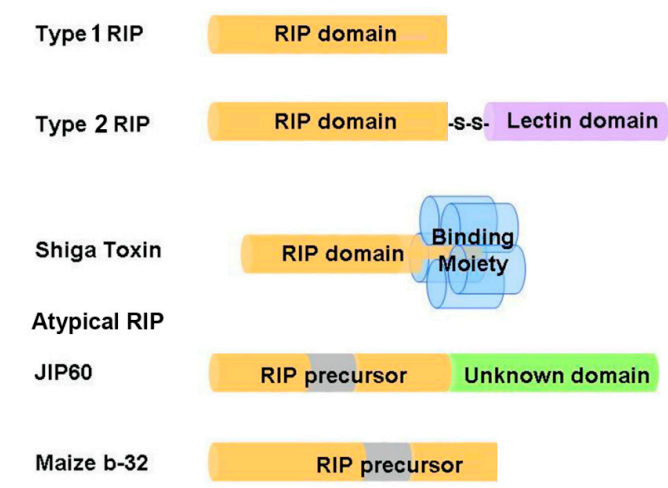

Figure 1. Schematic representation of the organization structures of ribosome-inactivating proteins (RIPs). The RIP domains are colored yellow; lectin domain is colored purple; binding moiety of Shiga toxin is colored blue; unknown domain is colored green; internal inactivation fragments being removed during maturation are colored gray. JIP60 $=$ jasmonate-induced protein.

Based on the number of subunits and the organization of the precursor sequences, RIPs are grouped into three types (Figure 1). Type 1 RIPs such as trichosanthin (TCS), pokeweed antiviral protein (PAP) and saporin (SO6) consist of a single polypeptide, with molecular weight around $28 \mathrm{kDa}$. Type 2 RIPs such as ricin and abrin consist of two polypeptide chains linked by a disulfide bridge, with molecular weight around $60-65 \mathrm{kDa}$. Chain A is the catalytic subunit that is homologous to type 1 RIPs, while chain B is a lectin domain that facilitates the intracellular delivery of chain A by interacting with glycoconjugates on the cell surface [4]. As a result, type 2 RIPs are in general more cytotoxic than type 1 RIPs. Some type 2 RIPs such as eublin and cinnomomin are less toxic because the sugar-binding amino acid residues in the lectin domain have impaired affinity for galactosides, resulting in a greatly reduced uptake of these RIPs [24]. Shiga toxin is a representative bacterial RIP, comprising a catalytic A subunit $(30 \mathrm{kDa})$ and five $B$ subunits $(7 \mathrm{kDa})$ that bind specifically to the glycolipid receptor on cell surface [25]. Atypical RIPs or type 3 RIPs such as maize b-32 and jasmonate-induced protein (JIP60) have unusual precursor sequence organization (Figure 1). Maize b-32 is synthesized from a large proenzyme [16]. During germination, the N-terminal and C-terminal pro-sequences and an internal fragment of the proenzyme precursor are removed by proteolysis to generate an active and basic protein of 248 residues (MOD) [26]. After removal of the internal fragment, the activity of MOD is at least 600-fold higher than immature maize RIPs [27]. JIP60 consists of an RIP domain and an unknown domain at the C-terminal and is activated upon deletion of the C-terminal domain and an internal 
fragment in the RIP domain [28]. As the Pfam protein families database [29] summarized, RIP domain not only has been found duplicated or triplicated in a protein, but it can also fuse with variant functional domains, such as peptidase C48, Uridine 5' -diphospho-glucuronosyltransferase, amino acid kinase, RNA recognition motif, reverse transcriptase, glycoside hydrolase family 18 domain etc. These additional domains may impart distinct functions to RIPs.

\section{Crystal Structure and Structural Comparison of RIPs}

In the Protein Data Bank (PDB), structures of more than 20 RIPs are available (Table 1). Although the amino acid sequence identity in RIPs is less than $50 \%$ and antibodies raised against one RIP usually do not cross-react with one another [16], the key residues of $N$-glycosidase catalytic subunit of RIPs are highly conserved. In general, the $N$-glycosidase subunit of RIPs contains two domains, the large N-terminal domain consists of six $\alpha$-helices and a six-stranded mixed $\beta$-sheet, while the small C-terminal domain consists of an anti-parallel $\beta$-sheet and an $\alpha$-helix with a bend in the middle ( $\alpha$-helix G and H) (Figure 2a). The invariant active site residues Y70, Y111, E160, R163, and W192 (reference to TCS sequence in PDB code 2JDL) are located in the cleft between the N-terminal and C-terminal domains (Figure 3a). At the C-terminal region, the hydrogen bonds L240-N-P35-O and L240-O-L37-N in TCS are highly conserved among the known structures. These hydrogen bonds are essential to maintain structure stability between the $\mathrm{N}$ - and C-terminal domains, and deletion of them has been shown to disrupt the folding of TCS [30]. The ribosomal protein binding site is located between the anti-parallel beta-sheets 9 and 10 in the C-terminal domain [31].

Table 1. Available structures of representative RIPs and their similarity in comparison with trichosanthin (TCS).

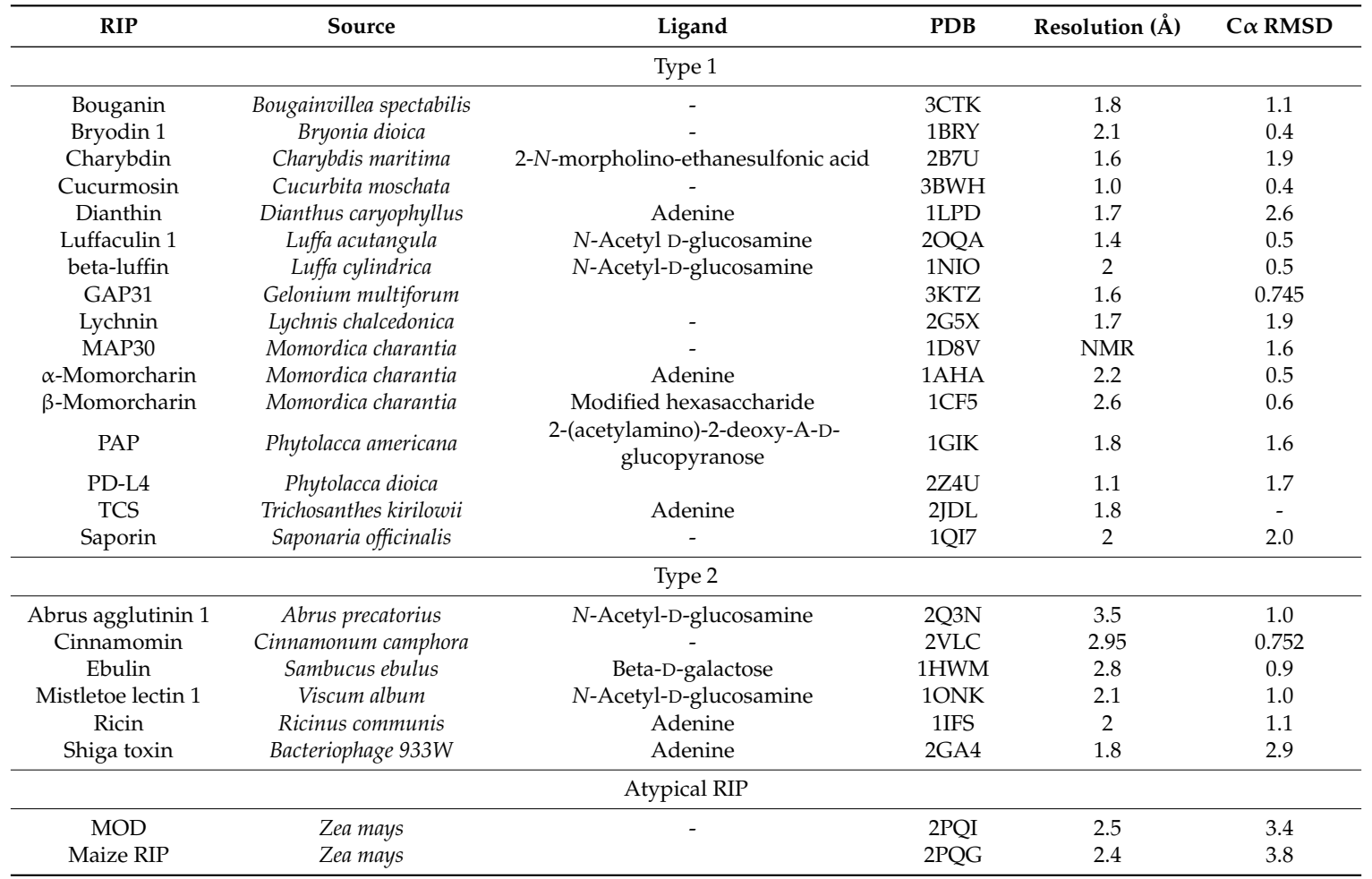

$\mathrm{C} \alpha$ RMSD (Root mean square deviation) with reference to TCS was calculated by PyMOL (De Lano Scientific, San Carlos, CA, USA) [32]. All the structures were solved by X-ray crystallography, except MAP30, which was solved by NMR. PDB = Protein Data bank; GAP 31 = Gelonium Anti-HIV Protein MW $31 \mathrm{kDa} ; \mathrm{MAP} 30$ = $($ Momordica Anti-HIV Protein, MW $30 \mathrm{KDa}$; PAP = pokeweed anti-viral protein; PD-L4 = The RIP from leaves of Phytolacca dioica; $\mathrm{MOD}=$ the active form of maize RIP. 
The structures of RIPs are, in general, well-conserved. For example, the overall root-mean-square deviation (RMSD) of TCS and RTA is $1.1 \AA$ (Table 1). Between TCS and RTA, the major differences occur in the $\mathrm{N}$-terminal domain, in which strands 2 and 3 are missing (Figure 2b). These two strands are far away from the active site. We have also compared the structures of RIPs that have RMSD $>2$ with TCS (Figure 2c). In saporin, $\beta$-strands 9 and 10 in the C-terminal domain are replaced by a short loop. Dianthin does not have strand 2. It has a long loop between strands 6 and 7 and a dissimilar C-terminal region. The structures of Shiga toxin and maize RIP are more deviated from TCS. In Shiga toxin, the C-terminal domain only reserves the bended $\alpha$-helices but has two extra $\alpha$-helices and four-stranded mixed $\beta$-sheets. For the mature form of the maize RIP, the $\alpha$-helix B and $\beta$-strand 8 in the large domain are missing and the anti-parallel $\beta$-strands 9 and 10 in the small domain are replaced by a short $\alpha$-helix. As shown in the structural comparison, the small domains are, in general, more varied. As discussed below, the small domains in several RIPs are shown to bind ribosomal $\mathrm{P}$ proteins. Structural variation of this domain may influence the specificity to the target ribosomal subunit.

In type 2 RIPs, the $N$-glycosidase domain (chain A) is linked with a lectin domain (chain B) by a disulfide bond. The chain $B$ binds to $\beta$-1,4-linked galactose residues on the cell surface and facilitates delivery of chain A. The overall structure of ricin chain B (RTB) is highly conserved and consists of two homologous domains arisen by gene duplication. Each domain is composed of $12 \beta$-strands and is arranged in a $\beta$-trefoil structure of three lobes $\alpha, \beta$, and $\gamma$ [33]. The sugar-binding pockets are located in $1 \alpha$ and $2 \gamma$ sub-domains in RTB, and consist of aspartic acid, valine, arginine and a variable aromatic residue to provide a sugar binding platform [34].

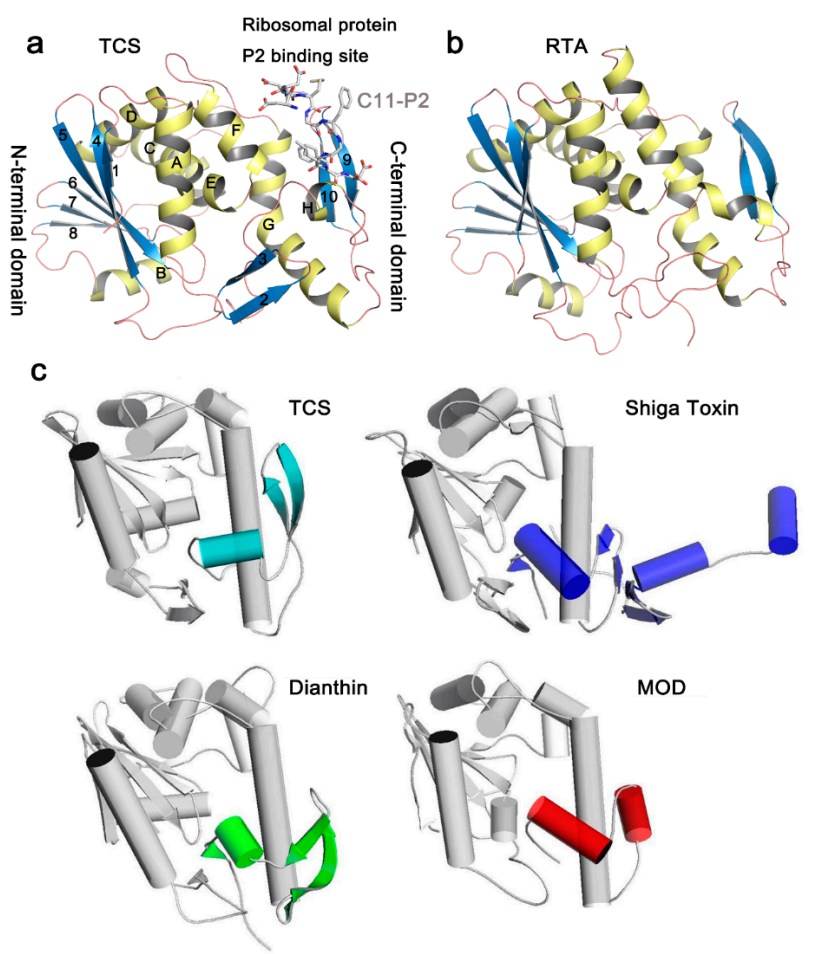

Figure 2. Representative structures and fold of RIPs. (a) Structure of TCS complexed with a C-terminal 11aa fragment of the ribosomal $\mathrm{P}$ protein (PDB code: 2JDL). The conserved secondary elements are labeled individually. $\alpha$-Helices are colored yellow, $\beta$-strands are colored blue and loops are colored pink. The last 11 residues of ribosomal stalk protein P2 (C11-P2) are shown as gray sticks; (b) The structure of the catalytic chain A of Ricin (RTA); (c) Structural comparison of selected RIPs with TCS. The C-terminal domain of TCS is colored light blue. Differences in the structural features compared to TCS are highlighted in the RIP. It is found that the N-terminal domains are more conserved among the RIPs. 

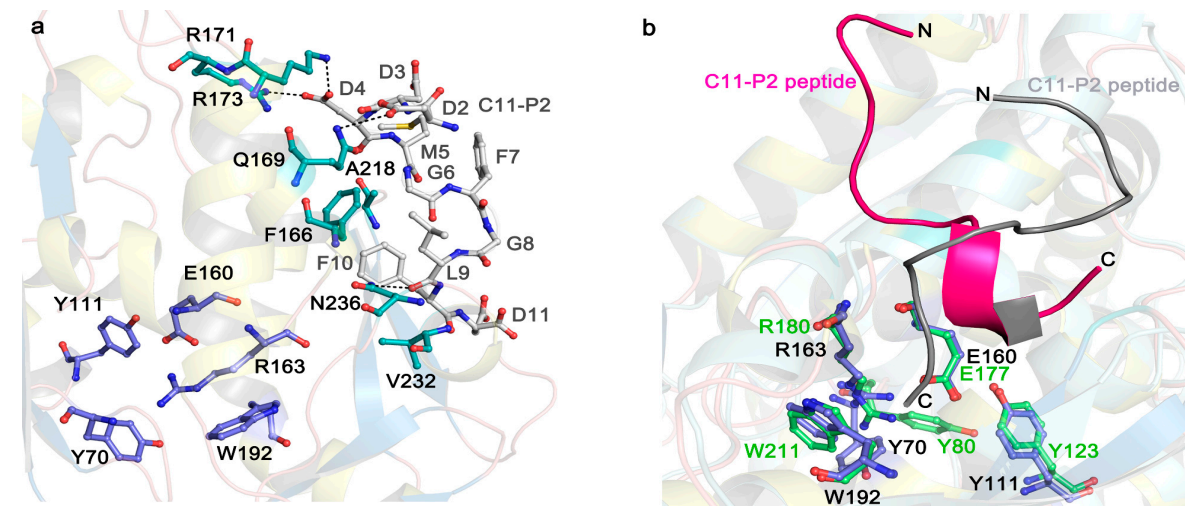

Figure 3. Stereo image on the active site and P2 binding mode of TCS (PDB code: 2JDL) and RTA (PDB code: 5GU4). (a) The active site and P2 binding pocket of TCS. The conserved active site residues in TCS are shown in purple sticks. The P2 binding residues are shown in cyan sticks. The C11-P2 peptide is shown as gray sticks. Hydrogen bonds are highlighted with black dash lines; (b) P2 peptide adopts distinct conformation for binding to TCS and RTA. The conserved active site residues in RTA are shown in green sticks. The magenta and gray colored C11-P2 peptides indicate the orientations of P2 peptide in binding to RTA and TCS, respectively.

\section{Invariant Residues in the Catalytic Subunit}

Sequence alignment of all these structure available RIPs indicates the existence of invariant residues, including Y14, R22, Y70, Y111, E160, R163, W192, and S196 as reference to TCS (Figure 4). Although Y14 and R22 are invariant, they are not crucial for the activity [35]. On the other hand, the active site residues Y70, Y111, E160, R163, and W192 are structurally conserved (Figure 3a). The orientation of the active site Y70 tyrosine ring is flexible and this may facilitate substrate binding. W192 lies at the bottom of the active site pocket, defines the binding site, stabilizes the ligand inside the cavity, and protects it from the solvent. The indole ring shows hydrophobic interaction with R163 and L241, which is essential for structure stability. S196 is located within $\alpha$-helix H near the active site and its side chain forms two hydrogen bonds with both backbone and side chain of active site W192, and is important for holding the indole ring and stabilize adenine binding. The mechanism of catalysis has been described previously [36].

In many RIPs, there are two key glutamate residues in the active site. In TCS, they are E160 and E189. The active site residue E160 serves to stabilize the ribooxocarbenium ion-like transition state intermediate, while E189 acts as back-up for the catalytic glutamate in case the latter is mutated $[37,38]$. However, maize RIP, Shiga toxin, and known RIPs of the Family Poaceae have only one glutamate in the active site. Structure-function study of maize RIP indicates the active site pocket of maize RIP is too small for two glutamate residues and it is suggested that maize RIP may be evolutionarily more related to bacterial RIPs [39].

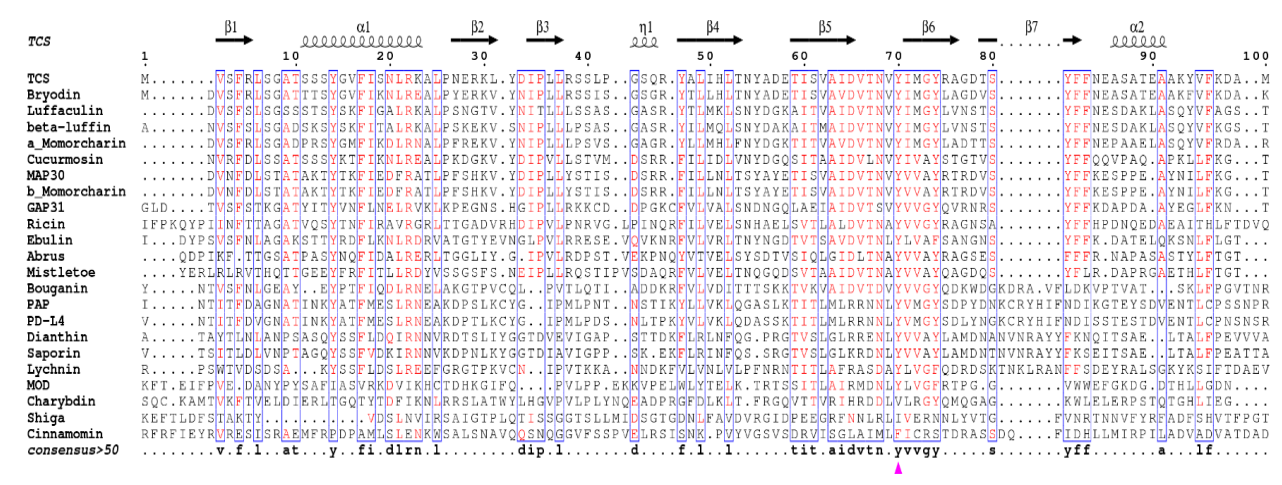

Figure 4. Cont. 

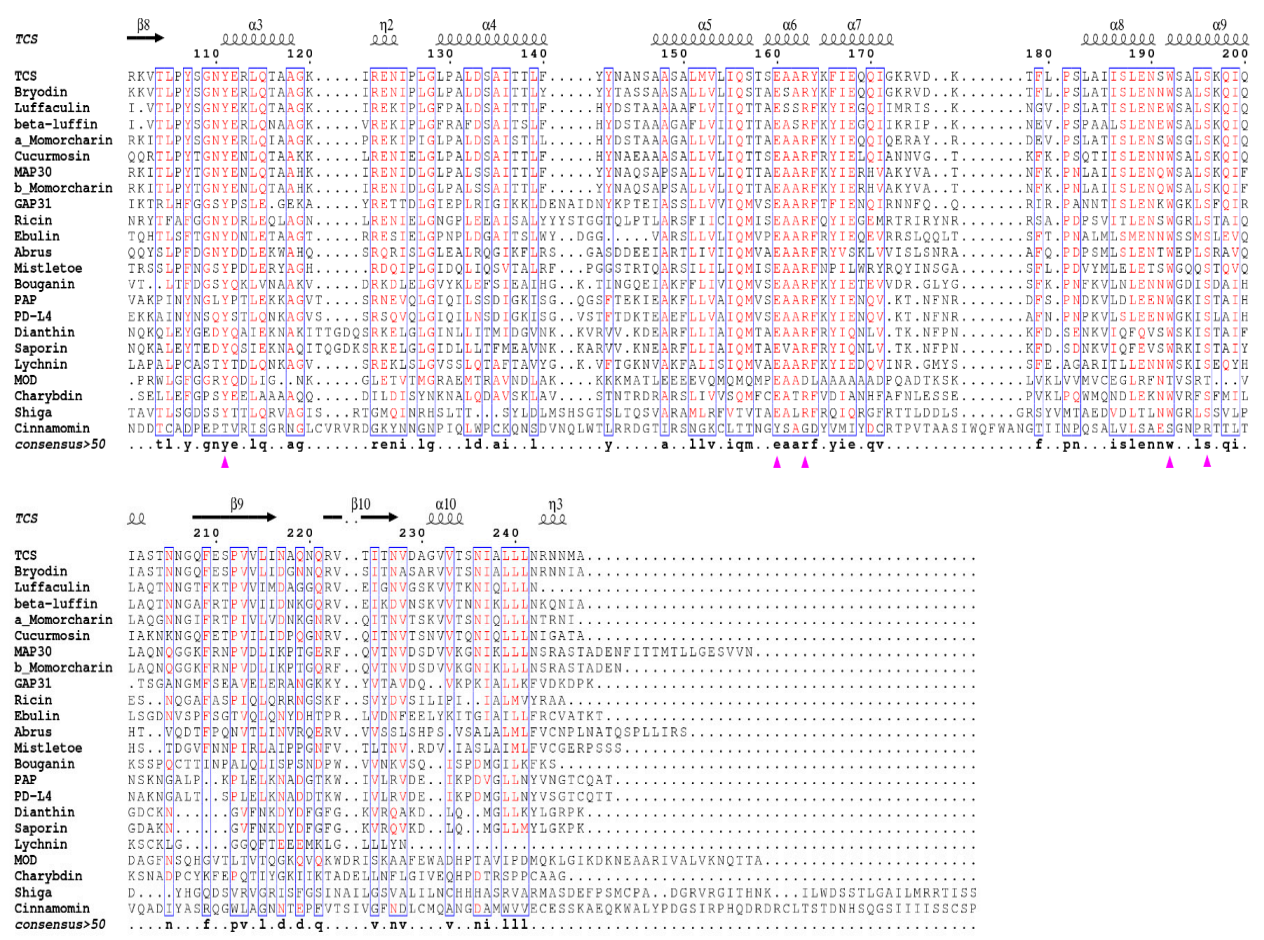

Figure 4. Structure based sequence alignment of structurally known RIPs. The catalytic A chains of all type 2 RIPs were used for sequence alignment. The sequence alignment was prepared by ENDscript 2 web server [40]. The conserved key residues of the active pocket of TCS (Y70, Y111, E160, R163, and W192) are marked with purple triangles. The top secondary structure elements are shown according to the crystal structure of TCS. The consensus sequences are highlighted with blue rectangles (consensus value $>50 \%$ ), the highly conserved residues are colored in red.

\section{The Interaction of RIPs with Ribosomes}

Although the target site of RIPs is a specific adenine residue in the 28S RNA, the presence of ribosomal proteins is essential for efficient catalysis. It was observed that the $\mathrm{k}_{\text {cat }}$ value of RTA on naked RNA is $10^{5}$-fold slower than on intact ribosome [10]. In PAP, the binding affinity on naked rRNA is 10-fold weaker than on intact ribosome [41]. Subsequently, RIPs have been shown binding to specific ribosomal proteins. For examples, TCS binds to the acidic ribosomal P proteins and L10a [31,42]; RTA binds to ribosomal protein L9 and P0 (=L10e) [43]; and PAP binds to L3 [41,44,45]. RTA and Shiga-like toxin 1 bind to the C-terminal region of $P$ protein [46] and depurination of ribosome is reduced when RTA is expressed in the Saccharomyces cerevisiae mutants with P1 or P2 deleted. These mutants are more resistant to the cytotoxicity of RTA [47]. These indicate that the ribosomal stalk facilitates the recruitment of some RIPs by transporting them to the spatial proximity of SRL. The known ribosomal proteins which were identified to interact with RIPs and their distribution around the target adenine of the $\alpha$-SRL are shown in Figure 5.

The early RTA and ribosome interaction studies showed that the electrostatic surfaces of RTA and ribosome are essential for the delivery of RTA to the surface of ribosome [48-50]. The target location may be achieved through the following steps: (i) the toxin is oriented for productive association and catalysis when it approaches the ribosome; (ii) the toxin is attracted to the ribosome even if they are far apart; and (iii) once the toxin binds to the ribosome, it is guided to the specific ribosomal subunit by the electrostatic field on the ribosome, probably through several association-dissociation processes [48-50]. The subsequent proposed two-step interaction model stated that the initial non-specific electrostatic interaction increases local concentration of RTA, facilitating the encounter and accelerating the reaction rate above the expected diffusion limit [51]. Then the more specific interaction of RTA with the ribosomal stalk pentamer facilitates the proximity to the $\alpha$-SRL of ribosomes [51,52]. This two-step 
model was confirmed by the kinetic observations that the interaction of RTA with intact pentameric ribosomal stalk fit well with a simple 1:1 interaction model, and the association rate constant of the RTA-intact stalk pentamer interaction was two-fold greater than its association rate with the stalk trimers, which contain only one P1/P2 heterodimer [53]. These results indicating multiple copies of the stalk proteins or intact ribosomal stalk pentamer can accelerate the recruitment of RTA to ribosome for depurination [52,53].

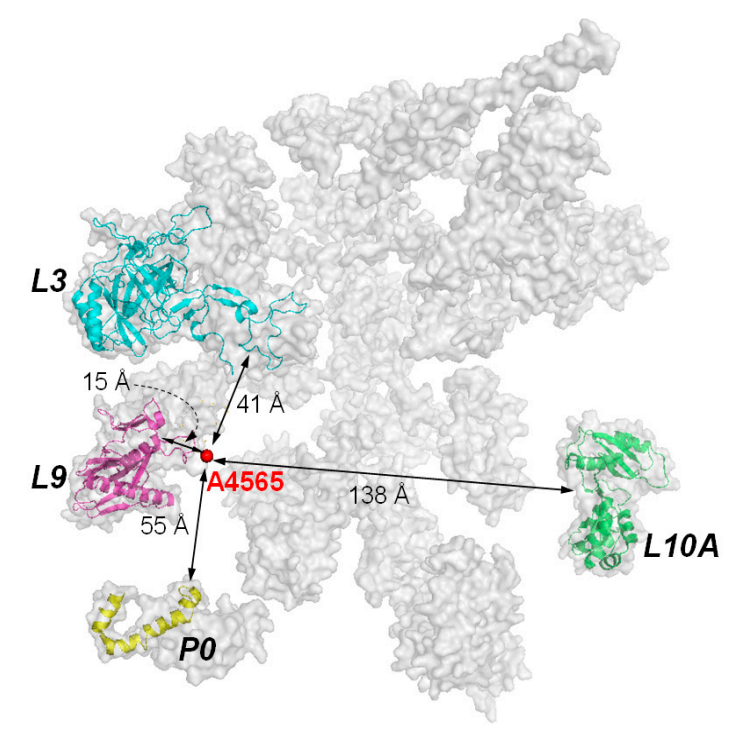

Figure 5. Ribosomal subunits that have been found to interact with RIPs. Subunits P0, L3, and L9 are clustered on a plane and within the vicinity of the targeted adenine. Subunit L10A is almost at the opposite side of the other three subunits. The interaction with the former three ribosomal subunits may be more relevant to the biological activity of RIPs, as variants of TCS with reduced interaction with $P$ proteins are less active in ribosome-inactivation. Model of mammalian ribosome is according to PDB, code 2ZKR.

Recent structural studies have revealed how eukaryotic stalk protein recruits TCS or RTA to ribosomes. The crystal structure of TCS and P protein C-terminal peptide complex [54] shows that three previously identified positively charged residues, K173, R174, and K177 [31,55] form favorable electrostatic interactions with the P protein peptide. Besides F166 and V232 (as shown in Figure 3a), other residues A184, L188, L215, and I225 around $4 \AA$ from P2 peptide may form a hydrophobic pocket for the interaction. Crystal structure of RTA-P2 peptide reveals that the binding manner of RTA and P protein peptide is similar to that with TCS. RTA donated a unique hydrophobic pocket to stabilize the C-terminal hydrophobic GFGLFD motif of P2 peptide, while the structurally untraced acidic SDDDM motif of P2 peptide was shown by biochemical interaction assays for charge-charge interaction with RTA (Figure 3b) [56]. The structural superposition of the TCS-P2 and RTA-P2 complexes demonstrated P2 peptide adopted distinct orientations and different interaction modes while binding to these two RIPs (Figure 3b). In SO6, K220, K226, and K234 in the C-terminal domain are protected by ribosome upon differential succinic anhydride modification [55]. Interestingly, these charged residues in SO6 are located in a region similar to that of TCS, indicating that the two proteins may use the similar site to interact with ribosome. Docking analyses showed that SO6 and Shiga toxin may interact with P proteins in a manner similar to TCS, of which there is a charge-charge interaction at the N-terminal region of the $\mathrm{P}$ peptide and hydrophobic interaction at the C-terminal region [54,57]. In the case of TCS and ribosome interaction, the structure of the full-length human P1/P2 revealed the well-folded N-terminal dimerization domain and a C-terminal domain, linked by a proline-alaline rich linker that can extend C-terminal tail up to $125 \AA$ [58]. The long flexible linker presumably plays an important role in reaching out to capture the elongation factors nearby $[59,60]$. Truncation of the linker region 
results in greatly reducing the depurination activity [58]. These observations suggest that the flexible linker may sweep around to recruit RIPs that are attracted by the ribosome and deposit them to the specific adenine on the $\alpha$-SRL. It has also been shown that the C-terminal tail and flexible linker of the ribosomal stalk are essential for binding the eukaryotic factors 2 (eEF2) [59,61,62]. After binding to eEF2, ribosomes can be protected from RIP depurination [63,64], suggesting that RIPs and eEF2 may compete for binding to the ribosomal stalk. Therefore, eukaryote-specific RIPs may hijack the elongation-factor recruiting function of ribosomal stalk in reaching the $\alpha$-SRL [57].

However, this approach of interaction may not be universal. Comparison of primary sequences shows that the residues located at the $\mathrm{C}$-terminal domain, which is responsible for $\mathrm{P}$ protein interaction in RIPs, are not conserved (Figure 4). Besides, for the PAP-ribosome interaction, N69, F90, N91, and D92 in the active site cleft of PAP are shown to be important for binding with L3 [41] and the C-terminal region of the P protein is not required for PAP to get access to the ribosome [65]. In maize RIP, the corresponding anti-parallel beta-sheets are replaced by a short $\alpha$-helix, and no positively charged residues are found. It has been shown that MOD, the active form of maize RIP, interacts with the conserved C-terminal peptide of P2 without hydrophobic interactions [66]. Four positively charged lysines K143-K146 in MOD were identified to be involved in interacting with the negatively charged DDD motif on P2 [67]. These positively charged amino acids on MOD are located at the base of the internal inactivating loop, which is removed for the activation of maize RIP.

\section{Kingdom Specificity of RIPs to Ribosome}

Apart from acting on eukaryotic ribosomes, PAP, dianthin, mirabilis antiviral protein, and Shiga toxin also capable of depurinating prokaryotic ribosomes at A2660 in 23S rRNA, the equivalent adenine in eukaryotic $28 \mathrm{~S}$ rRNA. The efficiency to prokaryotic ribosomes is about 100-500 times weaker [68] or comparable to eukaryotic ribosomes [69]. The target adenine in GAGA hairpin within the $\alpha$-SRL is conserved in most bacteria, plants, and animals. Some RIPs such as RTA do not act on prokaryotic ribosome but can depurinate naked $23 \mathrm{~S}$ rRNA [10]. Since the active site residues are invariant in all RIPs, it is possible that the ribosomal proteins play a role to determine the kingdom specificity of RIPs. For example, PAP was found to interact with L3, which is highly conserved in yeast, human, and E. coli, hence the access of ribosome through L3 may justify its dual specificity on eukaryotes and prokaryotes [47].

\section{Conclusions}

RIPs are potent toxins. On one hand, they may be used as bioweapons or cause food poisoning. On the other hand, they have good potential applications in pharmacology and biotechnology [70-72]. The RIP conjugated immunotoxins have exhibited promising tumor inhibition for clinical use [73,74]. For examples, SO6 and RTA immunotoxins can effectively kill lymphocytes in allograft-related diseases [75,76]. Besides, Shiga toxin can remove contaminated tumor cells in stem cell grafts [77]. TCS has been tested as anti- human immunodeficiency virus (HIV) agent [78] and used to induce mid-term abortion [36]. PAP and maize RIP are promising anti-insect and anti-fungal agents in transgenic plants $[39,79,80]$. Through fusing the transduction domains to type 1 RIP dianthin $[81,82]$ or saporin $[83,84]$, their intracellular routing can be altered for enhanced cytotoxicity and tumor inhibition. Besides, we have shown that the active form of maize RIP (MOD) protect chimeric simian-human immunodeficiency virus-infected macaque peripheral blood mononuclear cells from lysis ex vivo and transiently reduce plasma viral load in a simian-human immunodeficiency virus (SHIV) 89.6-infected rhesus macaque model [85]. The specificity of maize RIP to HIV-infected cells can be increased by fusing the HIV transduction peptide to the N-terminal of maize RIP and by introducing HIV-1 protease recognition sequences to the internal inactivation region of this protein $[85,86]$. With the potential uses of ribosome-inactivating proteins in different areas, it is important to understand how they inactivate ribosome and cause cell death. The evidence gathered so far indicates that ribosome binding is crucial for kingdom specificity and ribosome-inactivating activity of RIPs. On the ribosome, the P protein 
complex close to the $\alpha$-SRL, may offer a major site for RIP to bind and it is found that a common surface on some RIPs takes part in the interaction with the C-terminal region of P protein. Nevertheless, there remain some unsolved questions: (i) Some RIPs may bind to other ribosomal subunits. What is the significance of this binding and how many sites on the ribosome are available for RIPs to dock? (ii) Why some RIPs possess dual specificity? (iii) After docking on the ribosomal protein, how does the RIP find the target adenine? Further work on the ribosome recognition is required.

Acknowledgments: Research in ribosomal inactivating proteins was supported by One-off Funding for Research (Ref: C4045-14G) from The Chinese University of Hong Kong.

Author Contributions: Wei-Wei Shi and Amanda Nga-Sze Mak wrote the paper, collected information and references; Kam-Bo Wong and Pang-Chui Shaw supervised and revised the paper.

Conflicts of Interest: The authors declare no conflict of interest.

\section{References}

1. Stillmark, H. Uber ricin, eines gifiges ferment aus den samen von Ricinus communis L. Und anderen euphorbiacen. Ph.D. Thesis, University of Dorpat, Dorpat, Estonia, 1888.

2. Poisoning And Drug Overdose: Medicine, Toxicology, 5th ed.; Olson, K.R., Anderson, I.B., Eds.; McGraw-Hill Companies: New York, NY, USA, 2006.

3. Endo, Y.; Tsurugi, K. RNA N-glycosidase activity of ricin A-chain. Mechanism of action of the toxic lectin ricin on eukaryotic ribosomes. J. Biol. Chem. 1987, 262, 8128-8130. [PubMed]

4. Barbieri, L.; Battelli, M.G.; Stirpe, F. Ribosome-inactivating proteins from plants. Biochim. Biophys. Acta 1993, 1154, 237-282. [CrossRef]

5. Correll, C.C.; Munishkin, A.; Chan, Y.L.; Ren, Z.; Wool, I.G.; Steitz, T.A. Crystal structure of the ribosomal RNA domain essential for binding elongation factors. Proc. Natl. Acad. Sci. USA 1998, 95, 13436-13441. [CrossRef] [PubMed]

6. Lancaster, L.; Lambert, N.J.; Maklan, E.J.; Horan, L.H.; Noller, H.F. The sarcin-ricin loop of $23 \mathrm{~S}$ rRNA is essential for assembly of the functional core of the 50S ribosomal subunit. RNA 2008, 14, 1999-2012. [CrossRef] [PubMed]

7. Wang, P.; Tumer, N.E. Pokeweed antiviral protein cleaves double-stranded supercoiled DNA using the same active site required to depurinate rRNA. Nucleic Acids Res. 1999, 27, 1900-1905. [CrossRef] [PubMed]

8. Lacadena, J.; Alvarez-Garcia, E.; Carreras-Sangra, N.; Herrero-Galan, E.; Alegre-Cebollada, J.; Garcia-Ortega, L.; Onaderra, M.; Gavilanes, J.G.; del Martinez Pozo, A. Fungal ribotoxins: Molecular dissection of a family of natural killers. FEMS Microbiol. Rev. 2007, 31, 212-237. [CrossRef] [PubMed]

9. Collier, R.J. Understanding the mode of action of diphtheria toxin: A perspective on progress during the 20th century. Toxicon 2001, 39, 1793-1803. [CrossRef]

10. Endo, Y.; Tsurugi, K. The RNA N-glycosidase activity of ricin A-chain. The characteristics of the enzymatic activity of ricin A-chain with ribosomes and with rRNA. J. Biol. Chem. 1988, 263, 8735-8739. [PubMed]

11. Gasperi-Campani, A.; Brognara, I.; Baiocchi, D.; Roncuzzi, L. Mitochondrial DNA D-loop as a new target of saporin 6 nuclease activity. Toxicon 2005, 45, 475-480. [CrossRef] [PubMed]

12. Li, X.D.; Chen, W.F.; Liu, W.Y.; Wang, G.H. Large-scale preparation of two new ribosome-inactivating proteins-Cinnamomin and Camphorin from the seeds of Cinnamomum camphora. Protein Expr. Purif. 1997, 10, 27-31. [CrossRef] [PubMed]

13. Helmy, M.; Lombard, S.; Pieroni, G. Ricin RCA60: Evidence of its phospholipase activity. Biochem. Biophys. Res. Commun. 1999, 258, 252-255. [CrossRef] [PubMed]

14. Lee-Huang, S.; Kung, H.F.; Huang, P.L.; Bourinbaiar, A.S.; Morell, J.L.; Brown, J.H.; Tsai, W.P.; Chen, A.Y.; Huang, H.I. Human immunodeficiency virus type 1 (HIV-1) inhibition, DNA-binding, RNA-binding, and ribosome inactivation activities in the N-terminal segments of the plant anti-HIV protein GAP31. Proc. Natl. Acad. Sci. USA 1994, 91, 12208-12212. [CrossRef] [PubMed]

15. Day, P.J.; Lord, J.M.; Roberts, L.M. The deoxyribonuclease activity attributed to ribosome-inactivating proteins is due to contamination. Eur. J. Biochem. 1998, 258, 540-545. [CrossRef] [PubMed]

16. Motto, M.; Lupotto, E. The genetics and properties of cereal ribosome-inactivating proteins. Mini Rev. Med. Chem. 2004, 4, 493-503. [CrossRef] [PubMed] 
17. Toxic Plant Proteins, Plant Cell Monographs; Lord, J.M., Hartley, M.R., Eds.; Springer: Berlin/Heidelberg, Germany, 2010.

18. Girbes, T.; Ferreras, J.M.; Arias, F.J.; Stirpe, F. Description, distribution, activity and phylogenetic relationship of ribosome-inactivating proteins in plants, fungi and bacteria. Mini Rev. Med. Chem. 2004, 4, 461-476. [CrossRef] [PubMed]

19. Ribosome-Inactivating Proteins. Ricin and Related Proteins; Stirpe, F., Lappi, D.A., Eds.; Wiley Blackwell: Oxford, UK, 2014.

20. Reinbothe, S.; Reinbothe, C.; Lehmann, J.; Becker, W.; Apel, K.; Parthier, B. JIP60, a methyl jasmonate-induced ribosome-inactivating protein involved in plant stress reactions. Proc. Natl. Acad. Sci. USA 1994, 91, 7012-7016. [CrossRef] [PubMed]

21. Rippmann, J.F.; Michalowski, C.B.; Nelson, D.E.; Bohnert, H.J. Induction of a ribosome-inactivating protein upon environmental stress. Plant Mol. Biol. 1997, 35, 701-709. [CrossRef] [PubMed]

22. Dowd, P.F.; Holmes, R.A.; Pinkerton, T.S.; Johnson, E.T.; Lagrimini, L.M.; Boston, R.S. Relative activity of a tobacco hybrid expressing high levels of a tobacco anionic peroxidase and maize ribosome-inactivating protein against Helicoverpa zea and Lasioderma serricorne. J. Agric. Food Chem. 2006, 54, 2629-2634. [CrossRef] [PubMed]

23. Iglesias, R.; Citores, L.; Ragucci, S.; Russo, R.; Di Maro, A.; Ferreras, J.M. Biological and antipathogenic activities of ribosome-inactivating proteins from Phytolacca dioica L. Biochim. Biophys. Acta 2016, 1860, 1256-1264. [CrossRef] [PubMed]

24. Pascal, J.M.; Day, P.J.; Monzingo, A.F.; Ernst, S.R.; Robertus, J.D.; Iglesias, R.; Perez, Y.; Ferreras, J.M.; Citores, L.; Girbes, T. 2.8- $\AA$ crystal structure of a nontoxic type-II ribosome-inactivating protein, ebulin 1. Proteins 2001, 43, 319-326. [CrossRef] [PubMed]

25. Paton, J.C.; Paton, A.W. Pathogenesis and diagnosis of Shiga toxin-producing Escherichia coli infections. Clin. Microbiol. Rev. 1998, 11, 450-479. [PubMed]

26. Walsh, T.A.; Morgan, A.E.; Hey, T.D. Characterization and Molecular Cloning of a Proenzyme Form of a Ribosome-Inactivating Protein From Maize. Novel Mechanism of Proenzyme Activation by Proteolytic Removal of a 2.8-kiloDalton Internal Peptide Segment. J. Biol. Chem. 1991, 266, 23422-23427. [PubMed]

27. Hey, T.D.; Hartley, M.; Walsh, T.A. Maize ribosome-inactivating protein (b-32). Homologs in related species, effects on maize ribosomes, and modulation of activity by pro-peptide deletions. Plant Physiol. 1995, 107, 1323-1332. [CrossRef] [PubMed]

28. Chaudhry, B.; Muller-Uri, F.; Cameron-Mills, V.; Gough, S.; Simpson, D.; Skriver, K.; Mundy, J. The barley $60 \mathrm{kDa}$ jasmonate-induced protein (JIP60) is a novel ribosome-inactivating protein. Plant J. 1994, 6, 815-824. [CrossRef] [PubMed]

29. Finn, R.D.; Coggill, P.; Eberhardt, R.Y.; Eddy, S.R.; Mistry, J.; Mitchell, A.L.; Potter, S.C.; Punta, M.; Qureshi, M.; Sangrador-Vegas, A.; et al. The Pfam protein families database: Towards a more sustainable future. Nucleic Acids Res. 2016, 44, D279-D285. [CrossRef] [PubMed]

30. Chan, S.H.; Shaw, P.C.; Mulot, S.F.; Xu, L.H.; Chan, W.L.; Tam, S.C.; Wong, K.B. Engineering of a mini-trichosanthin that has lower antigenicity by deleting its C-terminal amino acid residues. Biochem. Biophys. Res. Commun. 2000, 270, 279-285. [CrossRef] [PubMed]

31. Chan, D.S.; Chu, L.O.; Lee, K.M.; Too, P.H.; Ma, K.W.; Sze, K.H.; Zhu, G.; Shaw, P.C.; Wong, K.B. Interaction between trichosanthin, a ribosome-inactivating protein, and the ribosomal stalk protein P2 by chemical shift perturbation and mutagenesis analyses. Nucleic Acids Res. 2007, 35, 1660-1672. [CrossRef] [PubMed]

32. DeLano, W. The Pymol Molecular Graphics System; DeLano Scientific: San Carlos, CA, USA, 2002.

33. Hartley, M.R.; Lord, J.M. Cytotoxic ribosome-inactivating lectins from plants. Biochim. Biophys. Acta 2004, 1701, 1-14. [CrossRef] [PubMed]

34. Hatakeyama, T.; Yamasaki, N.; Funatsu, G. Identification of the tryptophan residue located at the low-affinity saccharide binding site of ricin D. J. Biochem. 1986, 100, 781-788. [PubMed]

35. Shaw, P.C.; Mulot, S.; Ma, S.K.; Xu, Q.F.; Yao, H.B.; Wu, S.; Lu, X.H.; Dong, Y.C. Structure/function relationship study of Tyr14 and Arg22 in trichosanthin, a ribosome-inactivating protein. Eur. J. Biochem. 1997, 245, 423-427. [CrossRef] [PubMed]

36. Shaw, P.C.; Lee, K.M.; Wong, K.B. Recent advances in trichosanthin, a ribosome-inactivating protein with multiple pharmacological properties. Toxicon 2005, 45, 683-689. [CrossRef] [PubMed] 
37. Wong, K.B.; Ke, Y.B.; Dong, Y.C.; Li, X.B.; Guo, Y.W.; Yeung, H.W.; Shaw, P.C. Structure/function relationship study of Gln156, Glu160 and Glu189 in the active site of trichosanthin. Eur. J. Biochem. 1994, 221, 787-791. [CrossRef] [PubMed]

38. Robertus, J.D.; Monzingo, A.F. The structure of ribosome inactivating proteins. Mini Rev. Med. Chem. 2004, 4, 477-486. [CrossRef] [PubMed]

39. Mak, A.N.; Wong, Y.T.; An, Y.J.; Cha, S.S.; Sze, K.H.; Au, S.W.; Wong, K.B.; Shaw, P.C. Structure-function study of maize ribosome-inactivating protein: Implications for the internal inactivation region and the sole glutamate in the active site. Nucleic Acids Res. 2007, 35, 6259-6267. [CrossRef] [PubMed]

40. Robert, X.; Gouet, P. Deciphering key features in protein structures with the new ENDscript server. Nucleic Acids Res. 2014, 42, W320-W324. [CrossRef] [PubMed]

41. Rajamohan, F.; Ozer, Z.; Mao, C.; Uckun, F.M. Active center cleft residues of pokeweed antiviral protein mediate its high-affinity binding to the ribosomal protein L3. Biochemistry 2001, 40, 9104-9114. [CrossRef] [PubMed]

42. Chan, S.H.; Hung, F.S.; Chan, D.S.; Shaw, P.C. Trichosanthin interacts with acidic ribosomal proteins P0 and P1 and mitotic checkpoint protein MAD2b. Eur. J. Biochem. 2001, 268, 2107-2112. [CrossRef] [PubMed]

43. Vater, C.A.; Bartle, L.M.; Leszyk, J.D.; Lambert, J.M.; Goldmacher, V.S. Ricin A chain can be chemically cross-linked to the mammalian ribosomal proteins L9 and L10e. J. Biol. Chem. 1995, 270, 12933-12940. [PubMed]

44. Hudak, K.A.; Dinman, J.D.; Tumer, N.E. Pokeweed antiviral protein accesses ribosomes by binding to L3. J. Biol. Chem. 1999, 274, 3859-3864. [CrossRef] [PubMed]

45. Di, R.; Tumer, N.E. Expression of a truncated form of ribosomal protein L3 confers resistance to pokeweed antiviral protein and the fusarium mycotoxin deoxynivalenol. Mol. Plant Microbe Interact. 2005, 18, 762-770. [CrossRef] [PubMed]

46. McCluskey, A.J.; Poon, G.M.; Bolewska-Pedyczak, E.; Srikumar, T.; Jeram, S.M.; Raught, B.; Gariepy, J. The catalytic subunit of Shiga-like toxin 1 interacts with ribosomal stalk proteins and is inhibited by their conserved C-terminal domain. J. Mol. Biol. 2008, 378, 375-386. [CrossRef] [PubMed]

47. Chiou, J.C.; Li, X.P.; Remacha, M.; Ballesta, J.P.; Tumer, N.E. The ribosomal stalk is required for ribosome binding, depurination of the rRNA and cytotoxicity of ricin A chain in Saccharomyces cerevisiae. Mol. Microbiol. 2008, 70, 1441-1452. [CrossRef] [PubMed]

48. Garcia-Mayoral, F.; Garcia-Ortega, L.; Alvarez-Garcia, E.; Bruix, M.; Gavilanes, J.G.; del Pozo, A.M. Modeling the highly specific ribotoxin recognition of ribosomes. FEBS Lett. 2005, 579, 6859-6864. [CrossRef] [PubMed]

49. Korennykh, A.V.; Piccirilli, J.A.; Correll, C.C. The electrostatic character of the ribosomal surface enables extraordinarily rapid target location by ribotoxins. Nat. Struct. Mol. Biol. 2006, 13, 436-443. [CrossRef] [PubMed]

50. Korennykh, A.V.; Correll, C.C.; Piccirilli, J.A. Evidence for the importance of electrostatics in the function of two distinct families of ribosome inactivating toxins. RNA 2007, 13, 1391-1396. [CrossRef] [PubMed]

51. May, K.L.; Yan, Q.; Tumer, N.E. Targeting ricin to the ribosome. Toxicon 2013, 69, 143-151. [CrossRef] [PubMed]

52. Li, X.P.; Chiou, J.C.; Remacha, M.; Ballesta, J.P.; Tumer, N.E. A two-step binding model proposed for the electrostatic interactions of ricin A chain with ribosomes. Biochemistry 2009, 48, 3853-3863. [CrossRef] [PubMed]

53. Li, X.P.; Grela, P.; Krokowski, D.; Tchorzewski, M.; Tumer, N.E. Pentameric organization of the ribosomal stalk accelerates recruitment of ricin A chain to the ribosome for depurination. J. Biol. Chem. 2010, 285, 41463-41471. [CrossRef] [PubMed]

54. Too, P.H.; Ma, M.K.; Mak, A.N.; Wong, Y.T.; Tung, C.K.; Zhu, G.; Au, S.W.; Wong, K.B.; Shaw, P.C. The C-terminal fragment of the ribosomal $\mathrm{P}$ protein complexed to trichosanthin reveals the interaction between the ribosome-inactivating protein and the ribosome. Nucleic Acids Res. 2009, 37, 602-610. [CrossRef] [PubMed]

55. Savino, C.; Federici, L.; Ippoliti, R.; Lendaro, E.; Tsernoglou, D. The crystal structure of saporin SO6 from Saponaria officinalis and its interaction with the ribosome. FEBS Lett. 2000, 470, 239-243. [CrossRef]

56. Shi, W.W.; Tang, Y.S.; Sze, S.Y.; Zhu, Z.N.; Wong, K.B.; Shaw, P.C. Crystal structure of ribosome-inactivating protein ricin A chain in complex with the C-terminal peptide of the ribosomal stalk protein P2. Toxins 2016, 8, 296. [CrossRef] [PubMed] 
57. Choi, A.K.; Wong, E.C.; Lee, K.M.; Wong, K.B. Structures of eukaryotic ribosomal stalk proteins and its complex with trichosanthin, and their implications in recruiting ribosome-inactivating proteins to the ribosomes. Toxins 2015, 7, 638-647. [CrossRef] [PubMed]

58. Lee, K.M.; Yusa, K.; Chu, L.O.; Yu, C.W.; Oono, M.; Miyoshi, T.; Ito, K.; Shaw, P.C.; Wong, K.B.; Uchiumi, T. Solution structure of human $\mathrm{P} 1 * \mathrm{P} 2$ heterodimer provides insights into the role of eukaryotic stalk in recruiting the ribosome-inactivating protein trichosanthin to the ribosome. Nucleic Acids Res. 2013, 41, 8776-8787. [CrossRef] [PubMed]

59. Diaconu, M.; Kothe, U.; Schlunzen, F.; Fischer, N.; Harms, J.M.; Tonevitsky, A.G.; Stark, H.; Rodnina, M.V.; Wahl, M.C. Structural basis for the function of the ribosomal L7/12 stalk in factor binding and GTPase activation. Cell 2005, 121, 991-1004. [CrossRef] [PubMed]

60. Naganuma, T.; Nomura, N.; Yao, M.; Mochizuki, M.; Uchiumi, T.; Tanaka, I. Structural basis for translation factor recruitment to the eukaryotic/archaeal ribosomes. J. Biol. Chem. 2010, 285, 4747-4756. [CrossRef] [PubMed]

61. Nolan, R.D.; Grasmuk, H.; Drews, J. The binding of tritiated elongation-factors 1 and 2 to ribosomes from Krebs II mouse ascites-tumore cells. The influence of various antibiotics and toxins. Eur. J. Biochem. 1976, 64, 69-75. [CrossRef] [PubMed]

62. Bargis-Surgey, P.; Lavergne, J.P.; Gonzalo, P.; Vard, C.; Filhol-Cochet, O.; Reboud, J.P. Interaction of elongation factor eEF-2 with ribosomal P proteins. Eur. J. Biochem. 1999, 262, 606-611. [CrossRef] [PubMed]

63. Fernandez-Puentes, C.; Benson, S.; Olsnes, S.; Pihl, A. Protective effect of elongation factor 2 on the inactivation of ribosomes by the toxic lectins abrin and ricin. Eur. J. Biochem. 1976, 64, 437-443. [CrossRef] [PubMed]

64. Cawley, D.B.; Hedblom, M.L.; Houston, L.L. Protection and rescue of ribosomes from the action of ricin A chain. Biochemistry 1979, 18, 2648-2654. [CrossRef] [PubMed]

65. Ayub, M.J.; Smulski, C.R.; Ma, K.W.; Levin, M.J.; Shaw, P.C.; Wong, K.B. The C-terminal end of P proteins mediates ribosome inactivation by trichosanthin but does not affect the pokeweed antiviral protein activity. Biochem. Biophys. Res. Commun. 2008, 369, 314-319. [CrossRef] [PubMed]

66. Wong, Y.T.; Ng, Y.M.; Mak, A.N.; Sze, K.H.; Wong, K.B.; Shaw, P.C. Maize ribosome-inactivating protein uses Lys158-Lys161 to interact with ribosomal protein P2 and the strength of interaction is correlated to the biological activities. PLoS ONE 2012, 7, e49608. [CrossRef] [PubMed]

67. Yang, Y.; Mak, A.N.; Shaw, P.C.; Sze, K.H. Solution structure of an active mutant of maize ribosome-inactivating protein (MOD) and its interaction with the ribosomal stalk protein P2. J. Mol. Biol. 2010, 395, 897-907. [CrossRef] [PubMed]

68. Hartley, M.R.; Legname, G.; Osborn, R.; Chen, Z.; Lord, J.M. Single-chain ribosome inactivating proteins from plants depurinate Escherichia coli 23 S ribosomal RNA. FEBS Lett. 1991, 290, 65-68. [CrossRef]

69. Suh, J.K.; Hovde, C.J.; Robertus, J.D. Shiga toxin attacks bacterial ribosomes as effectively as eucaryotic ribosomes. Biochemistry 1998, 37, 9394-9398. [CrossRef] [PubMed]

70. Pizzo, E.; Di Maro, A. A new age for biomedical applications of ribosome inactivating proteins (RIPs): From bioconjugate to nanoconstructs. J. Biomed. Sci. 2016, 23, 54. [CrossRef] [PubMed]

71. Puri, M.; Kaur, I.; Perugini, M.A.; Gupta, R.C. Ribosome-inactivating proteins: Current status and biomedical applications. Drug Discov. Today 2012, 17, 774-783. [CrossRef] [PubMed]

72. Stirpe, F. Ribosome-inactivating proteins: From toxins to useful proteins. Toxicon 2013, 67, 12-16. [CrossRef] [PubMed]

73. Bolognesi, A.; Polito, L. Immunotoxins and other conjugates: Pre-clinical studies. Mini Rev. Med. Chem. 2004, 4, 563-583. [CrossRef] [PubMed]

74. Gilabert-Oriol, R.; Weng, A.; Mallinckrodt, B.; Melzig, M.F.; Fuchs, H.; Thakur, M. Immunotoxins constructed with ribosome-inactivating proteins and their enhancers: A lethal cocktail with tumor specific efficacy. Curr. Pharm. Des. 2014, 20, 6584-6643. [CrossRef] [PubMed]

75. Hess, P.R.; Barnes, C.; Woolard, M.D.; Johnson, M.D.; Cullen, J.M.; Collins, E.J.; Frelinger, J.A. Selective deletion of antigen-specific $\mathrm{CD}^{+} \mathrm{T}$ cells by MHC class I tetramers coupled to the type I ribosome-inactivating protein saporin. Blood 2007, 109, 3300-3307. [CrossRef] [PubMed]

76. Alexeev, L.P.; Dolbin, A.G.; Toptygin, A.Y.; Moysuk, Y.G.; Prokofiev, S.A.; Tonevitsky, A.G.; Sechkin, A.V.; Shumakov, V.A.; Khaitov, M.R. New method of kidney allograft pretreatment (six-year follow-up). Transplant. Proc. 2001, 33, 1240-1241. [CrossRef] 
77. LaCasse, E.C.; Bray, M.R.; Patterson, B.; Lim, W.M.; Perampalam, S.; Radvanyi, L.G.; Keating, A.; Stewart, A.K.; Buckstein, R.; Sandhu, J.S.; et al. Shiga-Like Toxin-1 Receptor on Human Breast Cancer, Lymphoma, and Myeloma and Absence From CD34 ${ }^{+}$Hematopoietic Stem Cells: Implications for Ex Vivo Tumor Purging and Autologous Stem Cell Transplantation. Blood 1999, 94, 2901-2910. [PubMed]

78. Parikh, B.A.; Tumer, N.E. Antiviral activity of ribosome inactivating proteins in medicine. Mini Rev. Med. Chem. 2004, 4, 523-543. [CrossRef] [PubMed]

79. Tumer, N.E.; Hudak, K.; Di, R.; Coetzer, C.; Wang, P.; Zoubenko, O. Pokeweed antiviral protein and its applications. Curr. Top. Microbiol. Immunol. 1999, 240, 139-158. [PubMed]

80. Nielsen, K.; Payne, G.A.; Boston, R.S. Maize ribosome-inactivating protein inhibits normal development of Aspergillus nidulans and Aspergillus flavus. Mol. Plant Microbe Interact. 2001, 14, 164-172. [CrossRef] [PubMed]

81. Lorenzetti, I.; Meneguzzi, A.; Fracasso, G.; Potrich, C.; Costantini, L.; Chiesa, E.; Legname, G.; Menestrina, G.; Tridente, G.; Colombatti, M. Genetic grafting of membrane-acting peptides to the cytotoxin dianthin augments its ability to de-stabilize lipid bilayers and enhances its cytotoxic potential as the component of transferrin-toxin conjugates. Int. J. Cancer 2000, 86, 582-589. [CrossRef]

82. Von Mallinckrodt, B.; Thakur, M.; Weng, A.; Gilabert-Oriol, R.; Durkop, H.; Brenner, W.; Lukas, M.; Beindorff, N.; Melzig, M.F.; Fuchs, H. Dianthin-EGF is an effective tumor targeted toxin in combination with saponins in a xenograft model for colon carcinoma. Future Oncol. 2014, 10, 2161-2175. [CrossRef] [PubMed]

83. Weyergang, A.; Selbo, P.K.; Berg, K. Photochemically stimulated drug delivery increases the cytotoxicity and specificity of EGF-saporin. J. Control. Release 2006, 111, 165-173. [CrossRef] [PubMed]

84. Bostad, M.; Kausberg, M.; Weyergang, A.; Olsen, C.E.; Berg, K.; Hogset, A.; Selbo, P.K. Light-triggered, efficient cytosolic release of IM7-saporin targeting the putative cancer stem cell marker CD44 by photochemical internalization. Mol. Pharm. 2014, 11, 2764-2776. [CrossRef] [PubMed]

85. Wang, R.R.; Au, K.Y.; Zheng, H.Y.; Gao, L.M.; Zhang, X.; Luo, R.H.; Law, S.K.; Mak, A.N.; Wong, K.B.; Zhang, M.X.; et al. The recombinant maize ribosome-inactivating protein transiently reduces viral load in SHIV89.6 infected Chinese rhesus macaques. Toxins 2015, 7, 156-169. [CrossRef] [PubMed]

86. Law, S.K.; Wang, R.R.; Mak, A.N.; Wong, K.B.; Zheng, Y.T.; Shaw, P.C. A switch-on mechanism to activate maize ribosome-inactivating protein for targeting HIV-infected cells. Nucleic Acids Res. 2010, 38, 6803-6812. [CrossRef] [PubMed] 